\begin{tabular}{l} 
JURNAL SAINS DAN INFORMATIKA \\
RESEARCH OF SCIENCE ANI) INFORMATIC v7.II \\
$\begin{array}{l}\text { vol.07 No.01(2021)1-7 } \\
\text { http://publikasi.lldikti10.id/index.php/jis/ }\end{array}$ \\
\hline
\end{tabular}

\title{
Pemanfaatan ANN untuk Prediksi Penjualan Online Industri Rumahan selama Pandemi Covid-19
}

\author{
Evi Yulia Susanti ${ }^{\mathrm{a}}$, , Efmi Maiyana ${ }^{\mathrm{b}}$ \\ aSistim Informasi, Ilmu Komputer, Universitas Dharmas Indonesia, eviaja798@ gmail.com \\ ${ }^{b}$ Manajemen Informatika, AMIK Boekittinggi, efmi_maiyana@yahoo.com \\ Submitted: 24-04-2021, Reviewed: 26-04-2021, Accepted 29-04-2021 \\ http://doi.org/10.22216/jsi.v7i1.234
}

\begin{abstract}
This research was motivated by the Covid-19 Pandemic which forced the government to impose large-scale restrictions so as to paralyze physical activity, This has a big impact on the people's economy, so one way to stay afloat and produce for the home industry is to sell online. The problem is whether online selling is the best solution to overcome the difficulties of physical activity, especially in trading during the Covid-19 pandemic? The purpose of this study is to train and test neural networks with the backpropagtion method to obtain accurate forecasting results. The data obtained were processed using research and development $(R \& D)$ methodology, namely the data was separated into 2 parts, to train networks and to test the performance of neural networks, then tested the validity of the two data, From the training that has been carried out using the Matlab application. 2011 succeeded in finding goals according to the predetermined error tolerance value, namely 0.02 on the $33 \mathrm{rd}$ epoch. From the test, we managed to find a goal according to the predetermined error tolerance value, which is 0.2 at the 100th epoch. From the validity test, the MAPE value was 0.32\%. The validation test results show a significant relationship between training and network testing, ANN is able to store knowledge for the next network testing
\end{abstract}

Keywords:Predictions, Artificial Neural Networks, Covid-19

\begin{abstract}
Abstrak
Penelitian ini dilatarbelakangi dari masa Pandemi Covid-19 yang memaksa pemerintah untuk memberlakukan pembatasan berskala besar sehingga melumpuhkan aktivitas fisik, hal ini berdampak besar terhadap perekonomian rakyat, maka salah satu cara untuk tetap bertahan dan memproduksi bagi industri rumahan adalah dengan berjualan online. Masalahnya adalah apakah penjualan online ini menjadi solusi terbaik untuk mengatasi kesulitan aktivitas fisik terutama dalam perdagangan selama pandemi Covid-19?. Tujuan dari penelitian ini yaitu melatih dan menguji jaringan syaraf tiruan dengan metode backpropagtion untuk mendapatkan hasil peramalan yang akurat. Data yang diperoleh diolah menggunakan metodologi research and development $(\mathrm{R} \& \mathrm{D})$ yaitu data dipisahkan menjadi 2 bagian, untuk melatih jaringan dan untuk menguji kinerja dari jaringan syaraf tiruan, kemudian dilakukan uji validitas terhadap kedua data tersebut. Dari pelatihan yang sudah dilakukan dengan menggunakan aplikasi Matlab.2011 berhasil menemukan goal sesuai nilai error toleransi yang sudah ditentukan yaitu 0,02 pada epoch ke 33. Dari pengujian, berhasil menemukan goal sesuai nilai error toleransi yang sudah ditentukan yaitu 0,2 pada epoch ke 100. Dari uji validitas diperoleh nilai MAPE 0,32\%. Hasil uji validasi menunjukkan hubungan yang signifikan antara pelatihan dan pengujian jaringan, JST mampu menyimpan knowledge untuk pengujian jaringan berikutnya.
\end{abstract}

Kata kunci:Peramalan, Jaringan Syaraf Tiruan, Covid-19.

(C) 2018 JurnalSains dan Informatika

\section{Pendahuluan}

Salah satu cara untuk tetap berjualan bagi pelaku industri rumahan selama pandemi Covid-19 adalah berjualan online, dengan penjualan online industri rumahan dapat tetap memproduksi dan bertahan dalam persaingan bisnis. Prediksi penjualan adalah salah satu cara yang efektif untuk melihat penggunaan teknologi informasi sebagai media perantara penjual dan pembeli. Salah satu bidang dalam jaringan syaraf tiruan dapat diaplikasikan dengan baik untuk melakukan prediksi adalah metode Backpropagation karena proses kerjanya yang berulang 
pada setiap tahapan pelatihan untuk mendapatkan model yang terbaik.[1]

Jaringan Syaraf Tiruan adalah sistem pemrosesan Soffa Zahara [9] penggunaan jaringan sayaraf tiruan informasi yang memiliki karakteristik mirip dengan untuk memprediksi indek harga saham gabungan, dari Jaringan Syaraf Biologis. JST dibentuk sebagai penelitian ini diperoleh nilai MSE yang dihasilkan sudah generalisasi model matematika dari jaringan syaraf memenuhi nilai kondisi yang diinginkan yaitu nilai MSE biologi, dengan asumsi bahwa: 1) Pemrosesan informasi $\leq 0.1$ artinya kesalahan peramalan yang terjadi tidak terjadi pada banyak elemen sederhana (Neuron), 2) besar.

Sinyal dikirmkan diantara neuron-neuron melalui penghubung-penghubung, 3) Pengubung antar neuron memiliki bobot yang akan memperkuat atau memperlemah sinyal. 4) Untuk menentukan output, setiap neuron menggunakan fungsi aktivasi yang dikenakan pada jumlahan input yang diterima. Besarnya output ini selanjutnya dibandingkan dengan suatu batas ambang.[2]

Beberapa penelitian tentang penggunaan jaringan syaraf tiruan untuk melakukan prediksi, yaitu penelitian yang dilakukan oleh B. Badieah[3] tentang penggunaan Jaringan Syaraf Tiruan untuk memprediksi nilai akhir mata kuliah mahasiswa dengan tujuan untuk mengurangi tingkat kegagalan mahasiswa dalam perkuliahan, dari penelitian ini diperoleh bahwa Jaringan Syaraf Tiruan dapat melakukan penelitian dengan Learning Rate sebesar 0,5. Kemudian penelitian yang dilakukan oleh Laila Sari Lubis [4] tentang pemodelan Jaringan Syaraf Tiruan untuk memprediksi awal musim hujan dengan menggunakan suhu permukaan laut, dari hasil pelatihan yang dilakukan diperoleh hasil bahwa Jaringan Syaraf Tiruan dapat melakukan prediksi sebesar 5\%. Selanjutnya penelitian yang dilakukan Harry Ganda Nugraha [5] tentang penggunaan Jaringan Syaraf Tiruan yang digunakan untuk memprediksi tingkat Inflasi, pada penelitian ini lebih menekankan kepada perbaikan nilai bobot untuk setiap pelatihan jaringan, hasil akhir dari penelitian ini adalah pelatihan Jaringan Syaraf Tiruan dengan Backpropagtion mengalami kendala yaitu Over fiting sehingga tidak dapat menggeneralisasi masalah.

Kemudian penggunaan metode Backpropagation dalam melakukan prediksi dilakukan oleh Nabila Putri Sakinah [6] yang menghasilkan implementasi metode Backpropagation dalam prediksi jumlah permintaan koran diperlukan data latih yang akan digunakan sebagai sumber pelatihan yang selanjutnya diproses pada tahap pengujian dimana bobot awal harus ditentukan, kemudian menentukan iterasi maksimum, menentukan Learning Rate dan memperoleh nilai MSE. Selanjutnya penelitian yang dilakukan oleh Musli Yanto [7] tentang penerapan algoritma Backpropagation untuk memprediksi jumlah pemesanan (Reservasi) kamar hotel ini menghasilkan nilai MSE 0,001, sehingga hasil dari prediksi ini dapat menjadi bahan pertimbangan keputusan bagi pihak manajemen hotel.

Penelitian yang dilakukan oleh Fachrudin Pakaja[8] yaitu peramalan penjualan mobil menggunakan jaringan syaraf tiruan diketahui bahwa jaringan Syaraf Tiruan
Dari beberapa penelitian dan tinjauan literatur yang telah dikemukakan, terlihat bahwa prediksi dapat membantu perusahaan mengambil keputusan, selain itu prediksi juga dapat membantu meningkatkan penjualan produk. Penjualan merupakan sebuah fase akhir yang penting dari bisnis. [10]

Peramalan penjualan yang dilakukan dari peneliti sebelumnya adalah berdasarkan data history penjualan pada periode sebelumnya menggunakan Jaringan Syaraf Tiruan metode Regresi Linier. Hal ini tentu dirasa kurang tepat dan kurang akurat. Peramalan yang tidak tepat dan tidak akurat menyebabkan kesalahan dalam menentukan sebuah strategi penjualan, oleh karena itu peramalan dalam penelitian ini menggunakan alat peramalan Jaringan Syaraf Tiruan metode Backpropagation fungsi aktivasi Logsig. Karena dengan metode ini dapat memberikan umpan balik, bila dibandingkan dengan metode yang lain metode Backpropagation fungsi aktivasi logsig lebih baik hasil peramalannya, karena dilakukan berulang-ulang.

Tujuan dari penelitian ini yaitu melatih dan menguji jaringan syaraf tiruan dengan metode Backpropagtion dengan fungsi aktivasi Logsig untuk mendapatkan hasil peramalan yang akurat dengan error terkecil sebagai alat peramalan penjualan online industri rumahan selama pandemi Covid-19.

\section{Tinjauan Pustaka}

Jaringan Syaraf Tiruan ditentukan oleh 3 hal: 1) Pola hubungan antar neuron (arsitektur jaringan), 2) Metode untuk menentukan bobot penghubung (metode training), 3) Fungsi aktivasi, seperti terlihat pada gambar 1 berikut:

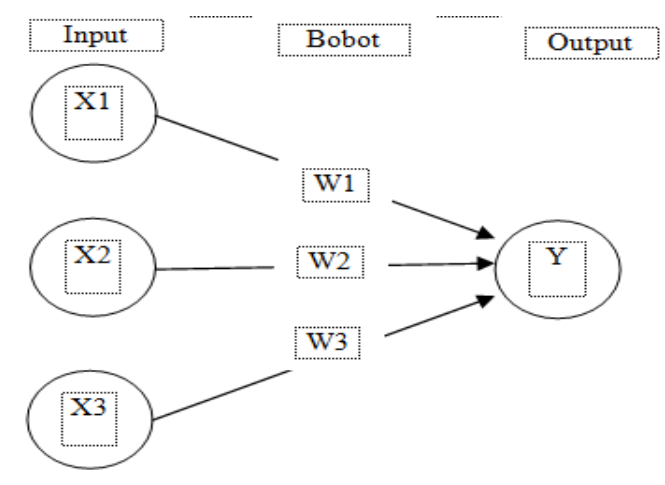

Gambar 1 Penentu Jaringan Syaraf Tiruan 
Sebagaimana terlihat pada gambar 1 di atas Y menerima input dari neuron $X 1, X 2$ dan $X 3$ dengan bobot hubungan masing-masing adalah W1, W2 dan W3. Ketiga impuls neuron yang ada dijumlahkan $N e t=X 1 W 1+X 2 W 2+X 3 W 3$. Besarnya impuls yang akan diterima oleh $\mathrm{Y}$ mengikuti fungsi aktivasi $\mathrm{Y}=$ $\mathrm{f}(\mathrm{net})$. Apabila nilai fungsi aktivasi cukup kuat, maka sinyal akan diteruskan. Nilai fungsi aktivasi juga dapat dipakai sebagai dasar untuk merubah bobot.

Fungsi aktivasi yang digunakan pada Jaringan Syaraf Tiruan untuk mengaktifkan atau tidak mengaktifkan neuron. Ada beberapa fungsi aktivasi yang sering digunakan dalam Jaringan Syaraf Tiruan yang disediakan pada Toolbox Matlab, antara lain:

Fungsi undak biner (hardlim), digunakan pada jaringan dengan lapisan tunggal untuk mengkonversi input dari suatu variabel yang bernilai kontinu ke suatu output biner (0 atau 1) sebagaimana terlihat pada formula 1 berikut:

$Y=\left\{\begin{array}{l}0, \text { jikax } \leq 0 \\ 1, \text { jikax }>0\end{array}\right.$

.dimana Y fungsi aktivasi, 0 dan 1 bilangan biner, $x$ nilai input.

Fungsi Bipolar (Hardlims), hampir sama dengan undak biner, hanya saja output yang dihasilkan berupa 1 atau 1. Pada Matlab fungsi ini lebih dikenal dengan nama hardlims dengan formula 2 berikut:

$Y=\left\{\begin{array}{c}1, \text { jika } x>0 \\ 0, \text { jika } x=0 \\ -1, \text { jika } x<0\end{array}\right.$

.dimana Y fungsi aktivasi, 0 dan 1 bilangan biner, $x$ nilai input.

Fungsi Linier (Purelin), memiliki nilai output yang sama dengan nilai inputnya. Pada Matlab fungsi aktivasi linier (identitas) dikenal dengan nama Purelin dengan formula 3 berikut:

$y=x$

.dimana y adalah output, $x$ nilai input. Fungsi Saturating Linier (Satlin), fungsi ini akan pada gambar 3, adalah arsitektur Backprogation dengan bernilai 0 jika inputnya kurang dari $-1 / 2$ dan akan $n$ buah masukan (ditambah sebuah bias), sebuah layer bernilai 1 jika inputnya lebih dari 1/2. Sedangkan jika tersebunyi yang terdiri dari $\mathrm{p}$ unit (ditambah sebuah nilai input terletak antara $-1 / 2$ dan $1 / 2$, maka outputnya bias) serta m buah unit keluaran.[13] akan bernilai sama dengan nilai input ditambah $1 / 2$. Dengan formula 4 di bawah ini.

$Y=\left\{\begin{array}{c}1 ; \text { jika } x \geq 0 \\ x+0,5 ; \text { jika }-0,5 \leq x \leq 0,5 \\ 0 ; \text { jika } x \leq 0\end{array}\right.$

dimana y output, 0 dan 1 bilangan biner, $x$ nilai input.

Fungsi Symetric Saturating Linier (Satlins), fungsi ini akan bernilai -1 jika inputnya kurang dari -1, dan akan bernilai 1 jika inputnya lebih dari 1 . Sedangkan jika nilai input terletak antara -1 dan 1, maka outputnya akan bernilai sama dengan inputnya. Pada matlab syntax yang digunakan adalah: $\mathrm{Y}=$ satlins(a)

$Y=\left\{\begin{array}{c}1 ; j i k a x \geq 1 \\ x ; j i k a-1 \leq x \leq 1 \\ -1 ; j i k a x \leq-1\end{array}\right.$

.dimana Y output, -1 dan 1 nilai fungsi, $x$ nilai input.

Fungsi Sigmoid Biner (Logsig), fungsi ini diguanakan untuk melatih jaringan dengan menggunakan metode Backpropagation. Fungsi sigmoid biner memiliki nilai pada range 0 sampai 1 . Oleh sebab itu, fungsi ini sering digunakan untuk Jaringan Syaraf Tiruan yang membutuhkan nilai output yang terletak pada interval 0 sampai 1, dengan formula 6 dibawah ini. [11]

$y=f(x)=\frac{1}{(1+e)}$

dimana y output, $x$ nilai input, $e$ eksponensial

Jaringan Syaraf Tiruan dapat dipakai untuk meramalkan apa yang akan terjadi di masa yang akan datang berdasarkan pola kejadian dimasa yang lampau. Ini dapat dilakukan mengingat kemampuan jaringan syaraf tiruan untuk mengingat dan membuat generalisasi dari apa yang sudah ada sebelumnya.

Metode Backpropagation (propagasi balik) adalah melatih jaringan untuk mendapatkan keseimbangan antara kemampuan untuk mengenali pola yang digunakan selama pelatihan serta kemampuan jaringan untuk memberikan respon yang benar terhadap pola masukan yang serupa dengan pola yang dipakai selama pelatihan.[12]

Backpropagation memiliki beberapa unit yang ada dalam satu atau lebih layar tersembunyi, seperti terlihat .

(1)

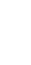




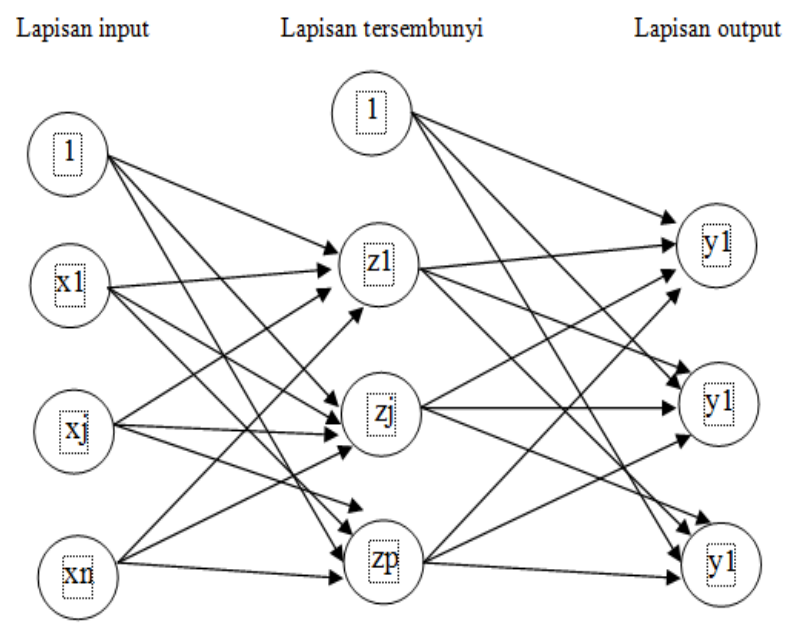

Gambar 2. Jaringan Syaraf Tiruan Backpropagation

\section{Metodologi Penelitian}

\subsection{Lokasi penelitian}

Penelitian ini dilakukan kepada pelaku industri rumahan yang terdapat di daerah Kabupaten Solok Provinsi Sumatera Barat.

\subsection{Bahan penelitian}

Bahan yang dibutuhkan untuk melakukan penelitian ini adalah data pelaku industri rumahan. Data diperoleh dengan cara memberikan daftar pertanyaan kepada pelaku industri rumahan, dengan jumlah sampel 175 orang. Data yang diperoleh dipisahkan menjadi 2 bagian, bagian pertama dipergunakan untuk melatih jaringan syaraf tiruan, bagian kedua dipergunakan untuk menguji kinerja dari jaringan syaraf tiruan, yaitu untuk menguji apakah jaringan menghasilkan output sesuai dengan yang diinginkan. Pada waktu input yang belum pernah dipelajari oleh jaringan. Semakin banyak data yang diperoleh, semakin baik jaringan dapat menyelesaikan masalahnya.

\subsection{Alat penelitian}

Alat yang digunakan dalam proses penelitian ini adalahseperangkat komputer dengan spesifikasi ram 3 $\mathrm{GB}$, prosesor intel core $\mathrm{i} 3$, HDD $320 \mathrm{~Gb}$, dan perangkat lunak yang digunakan untuk membangun sistem ini adalah Microsoft excel 2007 dan Matlab 2011

\subsection{Tahap-tahap penelitian}

Tahap pelaksanaan penelitian prediksi penjualan online industri rumahan ini dapat ditunjukkan pada gambar 3 berikut:

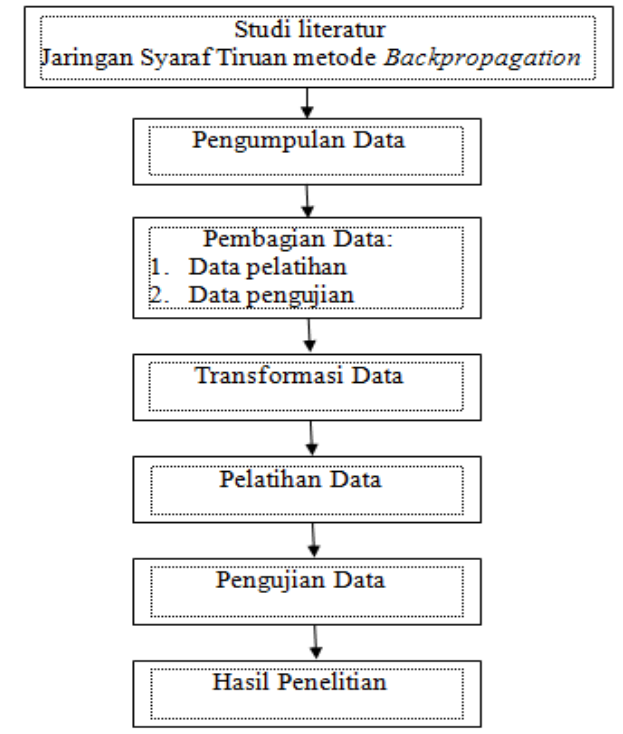

Gambar 3. Tahapan Penelitian

\subsection{Rancangan Metodologi Penelitian}

Rancangan penelitian ini adalah Research and Development $(R \& D)$ yaitu metode penelitian yang digunakan untuk menghasilkan produk tertentu dan menguji keefektifan metode tersebut.

\section{Hasil dan Pembahasan}

Sesuai dengan judul penelitian ini prediksi penjualan online bagi pelaku industri rumahan selama Pandemi Covid-19 menggunakan Jaringan Syaraf Tiruan, penulis melakukan penelitian selama dua bulan, yaitu bulan September-Desember 2020 yang ditujukan kepada pelaku industri rumahan yang berada di Kabupaten Solok yang berkoordinasi dengan dinas Kependudukan, Pemberdayaan Perempuan dan Perlindungan Anak, data dikumpulkan melalui daftar pertanyaan yang diberikan kepada pelaku industri rumahan, sebagaimana terlihat pada tabel 1 berikut:

Tabel 1. Daftar Pertanyaan

\begin{tabular}{|c|c|c|c|}
\hline No & Pertanyaan & & $\begin{array}{l}\text { Alternatif } \\
\text { Jawaban }\end{array}$ \\
\hline 1 & $\begin{array}{l}\text { Media elektronik apa saja yang } \\
\text { Bapak/Ibu kenal untuk menjual barang } \\
\text { dagangan? }\end{array}$ & $\begin{array}{l}\square \\
\square \\
\square \\
\square\end{array}$ & $\begin{array}{l}\text { Facebook } \\
\text { Whatshap } \\
\text { Twiter } \\
\text { Instagram }\end{array}$ \\
\hline 2 & $\begin{array}{l}\text { Selama pandemi Covid-19 ini, media } \\
\text { elektronik apa yang Bapak/Ibu sering } \\
\text { gunakan menjual barang dagangannya. }\end{array}$ & $\begin{array}{l}\square \\
\square \\
\square \\
\square\end{array}$ & $\begin{array}{l}\text { Facebook } \\
\text { Whatshap } \\
\text { Twiter } \\
\text { Instagram }\end{array}$ \\
\hline 3 & $\begin{array}{l}\text { Dari beberapa media yang Bapak/Ibu } \\
\text { gunakan, media mana yang lebih } \\
\text { banyak mengunjungi barang dagangan } \\
\text { Bapak/Ibu? }\end{array}$ & $\begin{array}{l}\square \\
\square \\
\square \\
\square\end{array}$ & $\begin{array}{l}\text { Facebook } \\
\text { Whatshap } \\
\text { Twiter } \\
\text { Instagram }\end{array}$ \\
\hline 4 & $\begin{array}{l}\text { Dari media elektonik yang ada, mana } \\
\text { yang lebih banyak Bapak/Ibu } \\
\text { melakukan transaksi elektronik? }\end{array}$ & $\begin{array}{l}\square \\
\square \\
\square \\
\square\end{array}$ & $\begin{array}{l}\text { Facebook } \\
\text { Whatshap } \\
\text { Twiter } \\
\text { Instagram }\end{array}$ \\
\hline
\end{tabular}


Menurut Bapak/Ibu media elektronik mana yang lebih efektif untuk memasarkan barang dagangan Bapak/Ibu?
Facebook Whatshap a Twiter I Instagram
Setelah dilakukan transformasi, maka diperoleh data hasil transformasi sebagaimana terlihat pada tabel 5dan tabel 6 berikut:
Setelah daftar pertanyaan sebagaimana terdapat pada tabel 1 diatas diisi oleh pelaku industri rumahan, langkah selanjutnya penulis mentelli jawaban dari responden, sehingga menghasilkan data sebagaimana terdapat pada tabel 2 berikut:

Tabel 2. Data input

\begin{tabular}{ccccc}
\hline Pertanyaan & \multicolumn{4}{c}{ Jawaban Responden } \\
\cline { 2 - 5 } & Facebook & Whatsapp & Twitter & Instagram \\
\hline 1 & 4 & 0 & 19 & 11 \\
2 & 3 & 5 & 14 & 8 \\
3 & 29 & 24 & 23 & 25 \\
4 & 69 & 47 & 58 & 55 \\
5 & 70 & 99 & 61 & 76 \\
$\sum$ & & & & 175 \\
Responden & 175 & 175 & 175 & 175 \\
\hline Sumber: Jawaban responden pelaku industri rumahan tahun 2020
\end{tabular}

Data input diatas dibagi dua, sebagaimana terlihat pada tabel 3 dan 4 di bawah ini.

\begin{tabular}{ccccc}
\hline \multirow{4}{*}{ Tabel 3. Data pelatihan } \\
\hline & \multicolumn{4}{c}{ Jawaban Responden } \\
\cline { 2 - 5 } & Facebook & Whatsapp & Twitter & Instagram \\
\hline 1 & 2 & 0 & 10 & 5 \\
2 & 2 & 3 & 7 & 4 \\
3 & 14 & 12 & 12 & 12 \\
4 & 34 & 23 & 29 & 27 \\
5 & 35 & 49 & 30 & 38 \\
& & & & 86
\end{tabular}

Tabel 4. Data pengujian

\begin{tabular}{ccccc}
\hline \multirow{2}{*}{ Pertanyaan } & \multicolumn{4}{c}{ Jawaban Responden } \\
\cline { 2 - 5 } & Facebook & Whatsapp & Twitter & Instagram \\
\hline 1 & 2 & 0 & 9 & 6 \\
2 & 1 & 2 & 7 & 4 \\
3 & 15 & 12 & 11 & 13 \\
4 & 35 & 24 & 29 & 28 \\
5 & 35 & 50 & 31 & 38 \\
$\sum$ Responden & 88 & 88 & 87 & 89 \\
\hline
\end{tabular}

Kemudian data mentah yang terdapat pada tabel 3 dan tabel 4 diatas diolah menggunakan fungsi aktivasi sigmoid (biner), maka data harus ditransformasikan terlebih dahulu dengan menggunakan rumus7:

$$
x^{\prime}=\frac{0.8(x-a)}{b-a}+0.1
$$

$x$ adalah nilai yang diperoleh dari responden, $a$ adalah nilai minimum dari semua nilai yang sudah dikumpulkan dari responden dan $b$ adalah nilai maksimum dari semua nilai yang sudah terkumpul.
Tabel 5. Data pelatihan yang sudah ditransformasi

\begin{tabular}{ccrcc}
\hline \multirow{2}{*}{ Pertanyaan } & \multicolumn{4}{c}{ Jawaban Responden } \\
\cline { 2 - 5 } & Facebook & Whatshap & twitter & Instagram \\
\hline 1 & 0,132653 & 0,1 & 0,263265 & 0,181633 \\
2 & 0,132653 & 0,14898 & 0,214286 & 0,165306 \\
3 & 0,328571 & 0,295918 & 0,295918 & 0,295918 \\
4 & 0,655102 & 0,47551 & 0,573469 & 0,540816 \\
5 & 0,671429 & 0,9 & 0,589796 & 0,720408 \\
\hline
\end{tabular}

Tabel 6. Data pengujian yang sudah ditransformasi

\begin{tabular}{crrrr}
\hline \multirow{2}{*}{ Pertanyaan } & \multicolumn{4}{c}{ Jawaban Responden } \\
\cline { 2 - 5 } & Facebook & Whatshap & Twitter & Instagram \\
\hline 1 & 0,132 & 0,1 & 0,244 & 0,196 \\
2 & 0,116 & 0,132 & 0,212 & 0,164 \\
3 & 0,34 & 0,292 & 0,276 & 0,308 \\
4 & 0,66 & 0,484 & 0,564 & 0,548 \\
5 & 0,66 & 0,9 & 0,596 & 0,708 \\
\hline
\end{tabular}

Kemudian data pada tabel 5 diatas dilakukan pelatihan jaringan dilakukan dengan mempergunakan Program Matlab. Untuk pelatihan menggunakan penurunan cepat, dengan menggunakan fungsi aktivasi sigmoid.

Dari pelatihan yang sudah penulis lakukan dengan menggunakan aplikasi Matlab 2011 sebagaimana terlihat pada gambar 4 di bawah berhasil menemukan goal sesuai nilai error toleransi yang sudah ditentukan yaitu 0,02 pada epoch ke 33, berikut penulis sajikan bentuk pola pelatihannya: jumlah neuron pada input layer adalah 5 neuron, jumlah neuron pada hidden layer adalah 3 neuron, toleransi error sebesar 0,025, learning rate sebesar 0,1, max epoch sebanyak 100 epoch.

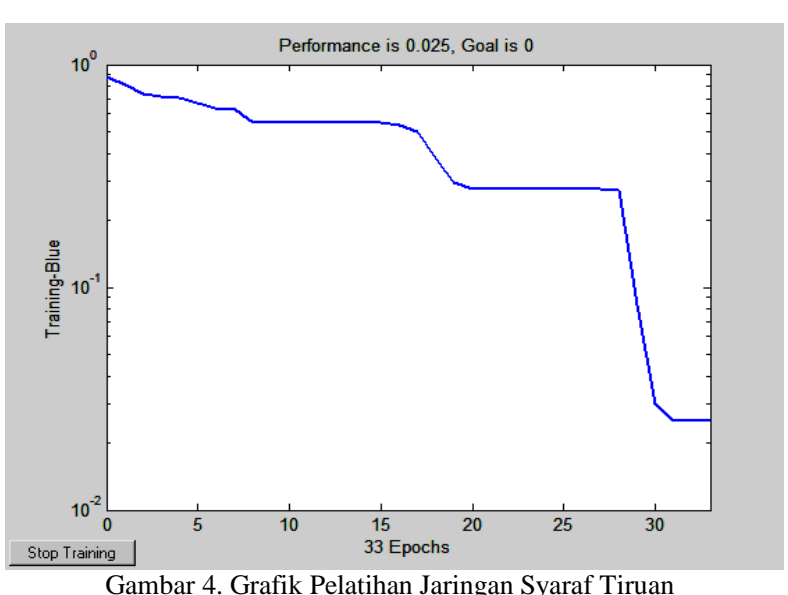

Kemudian penulis mencari nilai Mean Absolute Percentage Error (Mape) dengan menggunakan rumus 8:

Mape $=\frac{\sum\left(\frac{e}{x 1}\right)(100)}{n}$ 
.dimana $e$ adalah total error yang diperoleh disaat Setelah tahapan pelatihan dan pengujian dilakukan pelatihan jaringan, $x 1$ adalah total target dan $n$ adalah terhadap jaringan, maka dilakukan uji validitas banyak data.

$$
\begin{aligned}
\text { Mape } & =\frac{\sum\left(\frac{e}{x 1}\right)(100)}{n} \\
& =\frac{\left(\frac{0,0025}{0,1242}\right) \times 100}{5} \\
& =0,3354=0,33 \%
\end{aligned}
$$
didapatkan tabel perbandiangan berdasarkan nilai Mape, akurasi dan MSE sebagaimana terlihat pada tabel 7 di bawah ini.

\begin{tabular}{lcc}
\multicolumn{3}{c}{ Tabel 7. Perbandingan Pelatihan dan Pengujian Jaringan } \\
\hline Mape & Pelatihan & Pengujian \\
Akurasi & $0,33 \%$ & $0,32 \%$ \\
MSE & 98,07 & 99,38 \\
& 0,025 & 0,2 \\
\hline
\end{tabular}

Nilai Mape yang dihasilkan dari pelatihan jaringan adalah $0,33 \%$, sehingga nilai tingkat keakurasian 5. Kesimpulan pelatihan adalah 98,07\% dengan nilai MSE sebesar 0,025

Dari pelatihan jaringan yang sudah penulis lakukan, diperoleh hasil goal sesuai nilai error toleransi yang Langkah selanjutnya adalah pengujian, sebagaimana sudah ditentukan yaitu 0,02 pada epoch ke 33, dan nilai terlihat pada gambar 5 di bawah ini, berhasil Mean Absolute Percentage Error 0,33\%, artinya tingkat menemukan goal sesuai nilai error toleransi yang sudah kesalahan jaringan dalam melakukan pelatihan ditentukan yaitu 0,2 pada epoch ke 100 , pola tergolong kecil yaitu $0,33 \%$. kemudian dilakukan pengujiannya: jumlah neuron pada input layer adalah 5 pengujian jaringan diperoleh hasil goal sesuai nilai error neuron, jumlah neuron pada hidden layer adalah 4 toleransi 0,2 pada epoch ke 100 dan nilai Mean Absolute neuron, toleransi error sebesar 0,2, learning rate sebesar Percentage Error 0,32\%, artinya tingkat kesalahan 0,1, max epoch sebanyak 100 epoch.

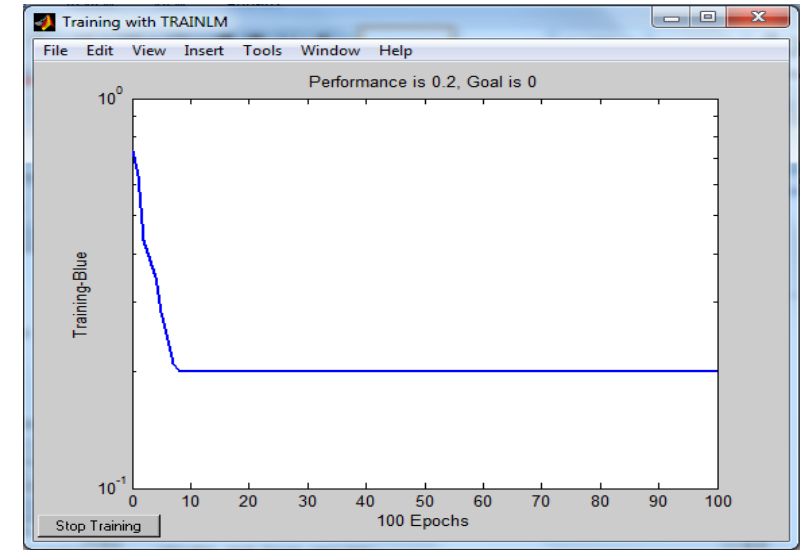

Gambar 5. Grafik Pengujian Jaringan Syaraf Tiruan

Nilai Mape sebagai berikut:

$$
\begin{aligned}
\text { Mape }= & \frac{\sum\left(\frac{e}{x 1}\right)(100)}{n} \\
& =\frac{\left(\frac{0,2}{0,1242}\right) \times 100}{5} \\
& =0,3220=32 \%
\end{aligned}
$$

Nilai Mape yang dihasilkan dari pengujian jaringan adalah $0,32 \%$, sehingga nilai tingkat keakurasian pelatihan adalah 99,38\% dengan nilai MSE sebesar 0,2 jaringan dalam tahap pengujian tergolong kecil yaitu $0,32 \%$, di sini terlihat korelasi signifikan antara pelatihan dan pengujian jaringan, jaringan mampu menyimpan knowledgeuntuk pengujian berikutnya. Dari hasil ini maka dapat disimpulkan bahwa jaringan syaraf tiruan dapat melakukan pelatihan dan pengujian dengan baik, dalam hal melakukan peramalan terhadap penjualan online yang dilakukan oleh industri rumahan selama masa pandemi Covid-19 menghasilkan prediksi yang tepat dan akurat, hasil prediksi ini dapat dijadikan pertimbangan untuk mengambil sebuah keputusan.

Penelitian ini masih bersifat umum yang bisa dikembangkan lagi kepada penjualan online yang lebih spesifik lagi, seperti penjualan online yang terdapat di marketplace.

\section{Daftar Rujukan}

[1] R. Sistem, D. Kartini, F. Abadi, and T. H. Saragih, "Prediksi Tinggi Permukaan Air Waduk Menggunakan Artificial Neural," vol. 1, no. 10, pp. 39-44, 2021.

[2] N. Suri, "Bab II Landasan Teori," J. Chem. Inf. Model., vol. 53, no. 9, pp. 1689-1699, 2019, doi: 10.1017/CBO9781107415324.004.

B. Badieah, R. Gernowo, and B. Surarso, "Metode Jaringan Syaraf Tiruan Untuk Prediksi Performa Mahasiswa Pada Pembelajaran Berbasis Problem Based Learning (PBL)," $J$. Sist. Inf. Bisnis, vol. 6, no. 1, p. 46, 2016, doi: 10.21456/vol6iss1pp46-58. 
[4] L. S. Lubis and A. Buono, "Pemodelan Jaringan [10] Syaraf Tiruan Untuk Memprediksi Awal Musim Hujan Berdasarkan Suhu Permukaan Laut Artificial Neural Network Modeling To Predict The Beginning of Rainy Season Based On Sea Surface Temperature," J. ilmu Komput. Agriinforatika, vol. 1, pp. 52-61, 2012.

[5] H. G. Nugraha et al., "Pelatihan Bobot Jaringan Syaraf Tiruan Menggunakan Particle Swarm Optimization untuk Peramalan Tingkat Inflasi," Bimipa, vol. 24, no. 3, pp. 292-302, 2017.

[6] N. P. Sakinah, I. Cholissodin, and A. W. Widodo, "Prediksi Jumlah Permintaan Koran Menggunakan Metode Jaringan Syaraf Tiruan Backpropagation," J. Pengemb. Teknol. Inf. dan Ilmu Komput., vol. 2, no. 7, pp. 2612-2618, 2018.

[7] M. Yanto, S. Defit, and G. W. Nurcahyo, "MEMPREDIKSI JUMLAH RESERVASI KAMAR HOTEL DENGAN METODE BACKPROPAGATION ( Studi Kasus Hotel Grand Zuri Padang )," J. KomTekInfo Fak. Ilmu Komput., vol. 2, no. 1, pp. 34-39, 2015.

[8] F. Pakaja and A. Naba, "Jaringan Syaraf Tiruan dan Certainty Factor," Neural Networks, vol. 6, no. 1, pp. 23-28, 2015.

[9] R. Sistem and S. Zahara, "Peramalan Data Indeks Harga Konsumen Berbasis Time Series," vol. 1, no. 10, pp. 24-30, 2021.
H. Aprilianto, S. Kumalaningsih, and I. Santoso, "Penerapan Jaringan Syaraf Tiruan Untuk Peramalan Penjualan Dalam Mendukung Pengembangan Agroindustri Coklat di Kabupaten Blitar," Habitat, vol. 29, no. 3, pp. 129-137, 2018, doi: 10.21776/ub.habitat.2018.029.3.16.

[11] Julpan, E. B. Nababan, and M. Zarlis, "Bipolar Dalam Algoritma Backpropagation Pada," J. Teknovasi, vol. 02, pp. 103-116, 2015.

[12] E. P. Cynthia and E. Ismanto, "Memprediksi Ketersediaan Komoditi Pangan Provinsi Riau," J. Teknol. Dan Sist. Inf. Univrab, vol. 2, no. 2, pp. 196-209, 2017.

[13] M. Agustin and T. Prahasto, "Penggunaan Jaringan Syaraf Tiruan Backpropagation Untuk Seleksi Penerimaan Mahasiswa Baru Pada Jurusan Teknik Komputer Di Politeknik Negeri Sriwijaya," J. Sist. Inf. Bisnis, vol. 2, no. 2, pp. 89-97, 2012, doi: 10.21456/vol2iss2pp089-097. 